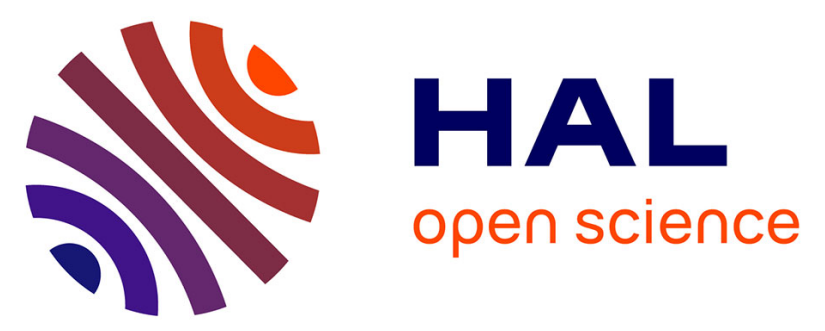

\title{
Numerical Reconstruction of Paleolithic Fires in the Chauvet-Pont d'Arc Cave (Ardèche, France)
}

Fabien Salmon, Catherine Ferrier, Delphine Lacanette, Jean-Christophe Mindeguia, Jean-Claude Leblanc, Carole Fritz, Colette Sirieix

\section{To cite this version:}

Fabien Salmon, Catherine Ferrier, Delphine Lacanette, Jean-Christophe Mindeguia, Jean-Claude Leblanc, et al.. Numerical Reconstruction of Paleolithic Fires in the Chauvet-Pont d'Arc Cave (Ardèche, France). Journal of Archaeological Method and Theory, 2020, 28, pp.604-616. 10.1007/s10816-020-09484-5 . hal-02929184

\section{HAL Id: hal-02929184 \\ https://hal.inrae.fr/hal-02929184}

Submitted on 24 Sep 2021

HAL is a multi-disciplinary open access archive for the deposit and dissemination of scientific research documents, whether they are published or not. The documents may come from teaching and research institutions in France or abroad, or from public or private research centers.
L'archive ouverte pluridisciplinaire HAL, est destinée au dépôt et à la diffusion de documents scientifiques de niveau recherche, publiés ou non, émanant des établissements d'enseignement et de recherche français ou étrangers, des laboratoires publics ou privés. 


\title{
Numerical Reconstruction of Paleolithic Fires in the Chauvet-Pont d'Arc Cave (Ardèche, France)
}

\author{
Fabien Salmon ${ }^{1}$ (D) $\cdot$ Catherine Ferrier ${ }^{2} \cdot$ Delphine Lacanette $^{1} \cdot$ \\ Jean-Christophe Mindeguia ${ }^{1}$ • Jean-Claude Leblanc ${ }^{3}$. Carole Fritz ${ }^{4}$. \\ Colette Sirieix ${ }^{1}$
}

\begin{abstract}
The Chauvet-Pont d'Arc Cave (Ardèche, France), famous for its remarkable rock art, also contains unique thermal-alterations such as rock spalling and color changes on the walls. These alterations resulted from intense fires that have not been observed in the other decorated caves thus far discovered. The functions of these unusual fires challenge archaeologists. To characterize these combustions, we used a numerical tool, previously validated with experimental data, to study the thermo-alterations in the Megaceros Gallery. This unprecedented approach in cave art research enabled us to assess the wood quantities and locations of the hearths responsible for the thermoalterations. We report here that at least ten fires took place in the Megaceros Gallery while burning more than $170 \mathrm{~kg}$ of wood. Both simulation and in situ observations suggest that the branches were arranged in a tepee shape and purposefully positioned, some distance from the walls. This method therefore enables further analysis of the functions of these fires.
\end{abstract}

Keywords Simulation $\cdot$ Fire $\cdot$ Chauvet-Pont d'Arc $\cdot$ Decorated cave $\cdot$ Aurignacian

Fabien Salmon

Salmon.Fabien@yahoo.com

Colette Sirieix

Colette.Sirieix@u-bordeaux.fr

1 Université de Bordeaux, CNRS, ENSAM, Bordeaux-INP, INRA, UMR 5295 I2M, 33405 Talence, France

2 Université de Bordeaux, UMR CNRS 5199 PACEA, Bâtiment B2 Allée Geoffroy Saint Hilaire, Pessac, France

3 Université de Toulouse, UMR CNRS 5608 TRACES, Allée Antonio Machado, 31058 Toulouse, France

4 CNRS, CREAP, USR 3414 MSHT, Maison de la Recherche, Allée Antonio Machado, 31058 Toulouse, France 


\section{Introduction}

In 1994, the discovery of the Chauvet-Pont d'Arc Cave (Ardèche, France) turned our perception of rock art upside down (Chauvet et al. 1995). On the one hand, the human activity in the cave extended from $37,000-36,200 \mathrm{cal}$ B.P. to $34,400-33,500 \mathrm{cal}$ B.P. (Aurignacian period) and from 31,400-30,700 to 29,700-27,900 cal B.P. (Gravettian period) (Quiles et al. 2014; Quiles et al. 2016). On the other hand, the skillful paintings and diversity of drawing techniques acutely challenged the so-called evolutionary scheme of rock art (Leroi-Gourhan 1965). These world-famous paintings (Clottes 2001), among the oldest known rock art, are accompanied by singular anthropogenic thermal-alterations on the upper part of some of the walls. The alterations are mostly observed (Fig. 2) in the Recess of the Bears (cumulative area of $3 \mathrm{~m}^{2}$ ), the Entrance Chamber $\left(11 \mathrm{~m}^{2}\right)$, the Chamber of the Bear Hollows $\left(25 \mathrm{~m}^{2}\right)$, and the Megaceros Gallery $\left(12 \mathrm{~m}^{2}\right.$ ). Their locations have already been thoroughly detailed (Ferrier et al. 2014).

These thermo-alterations correspond to (i) two limestone color changes (red and gray) (Chakrabarti et al. 1996; Liedgren et al. 2017) resulting from high-temperature chemical reactions and (ii) spalling caused by a coupled thermo-hydro-mechanical phenomenon (Mindeguia et al. 2015). The red color (rubification) is considered to appear after heating at $250{ }^{\circ} \mathrm{C}$ for $10 \mathrm{~min}$ (Walter et al. 2001; Ruan et al. 2002), while the gray color requires $350-400{ }^{\circ} \mathrm{C}$ for the same duration (Brodard et al. 2014). Each thermally altered area displays one or several types of thermo-alterations and soot deposits were often identified near them. Since the analysis of charcoal samples shows that Pinus sp. was used in the cave (Théry-Parisot et al. 2018), the thermo-alterations likely result from wood fires. Though fires occurred in other painted caves as well, only thermo-alterations on the floor (Medina-Alcaide et al. 2018) have been reported. The alterations of the walls in the Chauvet-Pont d'Arc Cave demonstrate that unparalleled intense fires burnt in this cave and their functions thus challenge archaeologists. At present, some explanations such as lighting, pigment production, sources to ignite torches, domestic fires, symbolic expressions, or protection against animals have been proposed (Ferrier et al. 2014; Medina-Alcaide et al. 2018). However, none of them is based on a quantitative analysis of the fires' characteristics.

To provide new clues, this investigation aims to characterize the hearths (mass, location, arrangement) that were burnt in the cave and to state the direct implications. Among all the altered areas (Ferrier et al. 2014), this paper specifically focuses on the Megaceros Gallery which is a narrow corridor located deep in the cavity (about $200 \mathrm{~m}$ from the Paleolithic entrance) containing rock art. This choice was instigated by the existence of photogrammetric surveys and the easy access to the thermo-alterations of the Megaceros Gallery. The thermo-alterations are particularly dense in this gallery, which varies in size from 3 to $6 \mathrm{~m}$ wide and around $2 \mathrm{~m}$ in height. Two large chambers (Hillaire Chamber and End Chamber), which host the two major panels of the cave, adjoin the Megaceros Gallery. The thermoluminescence dates (36,900 $\pm 2300 \mathrm{cal}$ B.P.) of heated samples (Guibert et al. 2015), the radiocarbon dates of charcoal samples, and drawings in the Megaceros Gallery coincide with the first human occupation of the cave during the Aurignacian period (Valladas et al. 2005; Quiles et al. 2014).

For the sake of conservation, only numerical tools can reproduce fires in the Chauvet-Pont d'Arc Cave geometry. We thus developed a model to simulate the fires 
and the induced thermo-alterations on the walls (Salmon et al. 2019; Salmon et al. 2020). The numerical method is described in the following section. Using this innovative tool, this investigation corresponds to the resolution of an inverse problem without archaeological excavations: which hearths were the most prone to produce the observed thermo-alterations in the Megaceros Gallery? To achieve this goal, we tested several fire scenarios and compared both resulting color changes (red and gray) with the in situ observations for each fire. We then conducted a thermo-mechanical analysis of the most likely scenario to check whether the rock spalling that is observed in the cave can result from it.

\section{Materials and Methods}

\section{Numerical Modeling}

Numerical simulation corresponds to the theoretical reproduction of processes from the mathematical equations describing them. This field is becoming increasingly pervasive due to continual augmentation of computing capacity. This paper presents the results of fire simulations and their impacts on cave walls. The various physical mechanisms must then be considered: combustion, chemistry, gas production, toxicity, fluid mechanics, air circulation, thermal radiation, heat transfers, and thermo-mechanics. The interaction between these physical processes makes the predictions of fire characteristics complex and time-consuming. Before this investigation, no tool could directly manage the simulation of all these phenomena and it was necessary to build an appropriate multiphysics code. Moreover, the simulation of fires in a large irregular geometry, such as a cave, had never been achieved before since this particularity causes extra difficulty.

First, the open source code FireFOAM (FireFOAM 2019), which can manage the simulation of fires, was extended. The contributions are briefly itemized here since they have already been detailed (Salmon et al. 2019; Salmon et al. 2020). A thermal boundary condition, based on energy balance at walls, has been added. The model considers wet walls for the wall temperature calculation. The soot deposit calculation through the Beresnev-Chernyak model (Beresnev and Chernyak 1995) was implemented. A thorough investigation of dangers such as toxicity (Speitel 1996), radiation and temperature (Purser and McAllister 2016) can now give information about the living conditions. A mathematical assumption about horizontal velocity was developed to reach consistent thermal stratifications. Last, a thermocouple correction was implemented to the code to enable comparisons of the experimental data with the numerical temperatures. Indeed, a solid sensor does not directly measure the gas temperature because of heat fluxes at the boundary and a rectification is needed to get the gas temperature.

Second, FireFOAM was coupled with Cast3m (Cast3m 2019), which is usually employed for mechanical problems. This second code can estimate the mechanical stress in rock due to the thermal expansion of limestone and thus provide information about the spalling probability. The coupling corresponds to Python scripts, which are available online (Coupling 2019). The resulting tool enables the simulation of fires, danger assessment, soot deposit, color changes and spalling (Salmon et al. 2020). 
Third, the designed code was validated with experimental wood fires in a quarry (Ferrier et al. 2017; Salmon et al. 2018; Salmon et al. 2019; Salmon et al. 2020). The L-shaped quarry consists of limestone. It is composed of two nine meters galleries and their dimensions are similar to those of the Megaceros Gallery: approximately $2 \mathrm{~m}$ in height and $2.5 \mathrm{~m}$ in width. The protocol involved $135 \mathrm{~kg}$ of Pinus sylvestris which were progressively brought in the flames by firemen with security equipment for $45 \mathrm{~min}$. The initial hearth consisted of approximately $16 \mathrm{~kg}$ of wood and firemen supplied the fire with two $4.5 \mathrm{~kg}$ bundles step by step. This mass approximately corresponds to the quantity of branches that can be easily brought under one arm without being too cumbersome. The length of the branches was approximately $80 \mathrm{~cm}$ since this naturally corresponds to the length of the branches broken on knees. In addition, this makes the shipping of wood easier than with big branches. Their diameters were smaller than $4 \mathrm{~cm}$ because breaking bigger branches of Pinus sylvestris appeared difficult without modern tools. We chose tepee-shaped hearths since this appears the best way to alter the ceiling of the quarry according to preliminary tests. This configuration indeed leads to tall flames while the same wood mass in a "flat" arrangement leads to smaller and larger flames. This protocol was conducted three times over 3 days to challenge the reproducibility of such a fire. Moreover, the quarry was instrumented with thermocouples, velocity sensors, gas and particle concentration sensors, and plates for soot deposit. The experimental data allowed us to adjust several model constants to obtain consistent results (Salmon et al. 2019; Salmon et al. 2020).

\section{Energy Source Modeling}

The input parameter of the created tool is the power released by wood combustion as a function of time. A link between the wood mass, which is the archaeological input parameter, and the energy released by its combustion must be established. At present, this information remains unattainable by mathematical theories. Instead, an empirical approach is necessary to know how much energy combustion releases. The wood crib model (Babrauskas 2016) is based on experimental fires of wood crib structures. This provides the heat release rate of wood cribs depending on time. However, this kind of structure burns differently from tepee hearths even if the same trend is observed. We therefore conducted additional fire experiments in the same quarry to measure the heat release rate of pine tepee hearths. Several wood masses were successively tested: $16 \mathrm{~kg}$, $32 \mathrm{~kg}, 40 \mathrm{~kg}, 60 \mathrm{~kg}$, and $90 \mathrm{~kg}$. The wood crib model constants were modified to fit the data acquired during the five fires. This modeling establishes the link between the mass of pine and the input parameter of the developed code.

\section{Method of Investigation}

The tool previously described has been applied to the thermo-alterations of the Megaceros Gallery. The 3D geometry of the Chauvet-Pont d'Arc Cave was obtained by lasergrammetry (MC, Perazio Engineering, Archéovision Production). The simulations are based on a mesh of the cave geometry (Fig. 1) achieved by the tool cfMesh (cfMesh 2019). The mesh consists of small cells $(3 \times 3 \times 3 \mathrm{~cm})$ in the flames, mediumsized cells $(6 \times 6 \times 6 \mathrm{~cm})$ in the area of interest, and then doubled in size as the distance increases. About 700,000 cells make up the cave mesh. For each thermally altered area, 

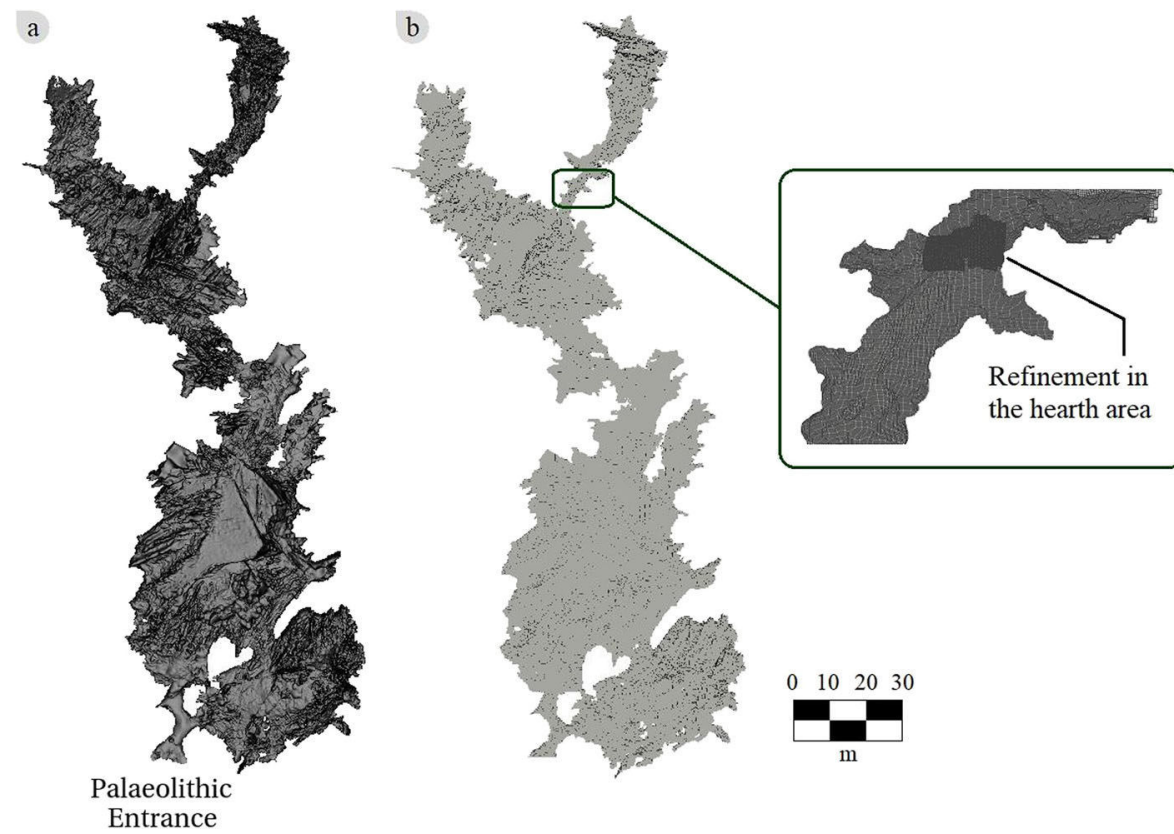

Fig. 1 a Geometry of the cave acquired by lasergrammetry (MC, Perazio, Archéovision Production). b Mesh of the cave achieved by version 1.1.2 of cfMesh

several fire scenarios were run. The more likely location of each hearth was first identified. From this fireplace, the color changes induced by the combustion of several wood masses were then tested. The wood mass, which yields color changes analogous to the observable ones, was then selected for the thermo-mechanical study. This analysis ensures that this mass leads to spalling similar to that observed in the cave. To assess the fire hazards, the air was assumed to be saturated since it is the most reliable hypothesis in a cave. The simulations were conducted on a supercomputer Bullx DLC with $10 \times 24$ cores Intel Haswell-EP Xeon 12-Cores E5-2690 V3 2.6 GHz. Each fire scenario required three days of calculation.

\section{Results}

Because no remains of fires have been observed on the floor of the gallery, the locations of the hearths are unknown a priori. Ferrier et al. (C. Ferrier et al. 2014) give potential explanations about the lack of hearths remnant (overlapping, erosion, displacement by humans or bears). Based on our in situ wall and ceiling observations, which suggest several thermally altered areas (C. Ferrier et al. 2014), the numerical study has allowed us to locate ten hearths (Fig. 2). The simulations enable us to estimate the wood mass associated with each area as well. The hearths were composed of approximately ten to thirty-five kilograms of pine depending on the location (Table 1). The combustion of these quantities leads to consistent color changes and relevant spalling probabilities (Fig. 3). Although successive smaller fires at the same locations could have produced analogous color changes, spalling would not likely have 


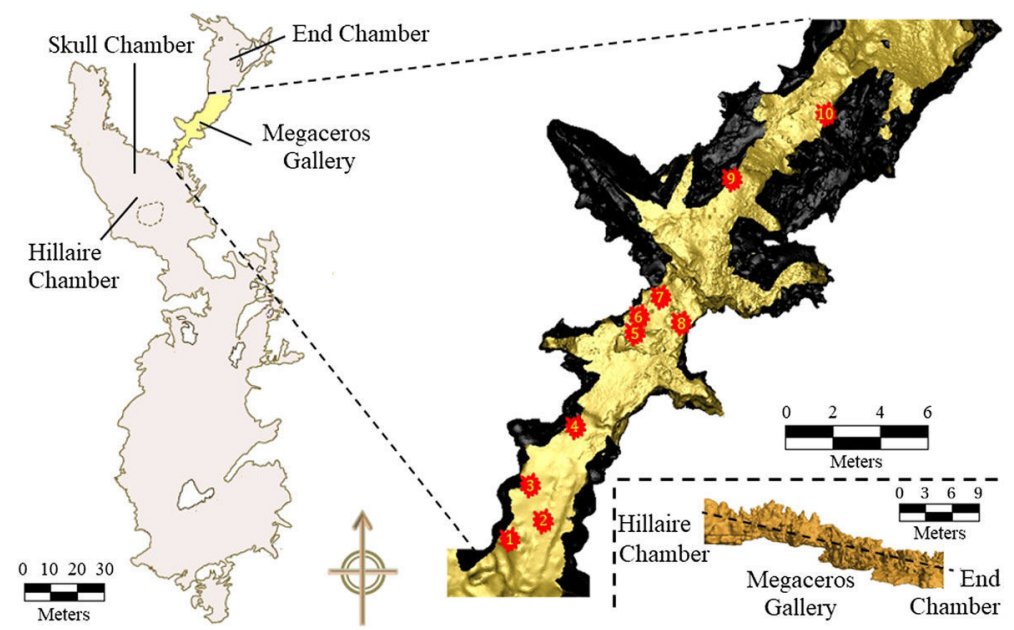

Fig. 2 Left: map of the Chauvet-Pont d'Arc Cave. Right: cutaway view of the Megaceros Gallery with the likely combustion sites from which the thermo-alterations were generated. The yellow part corresponds to the floor and the black part to the walls. The cutaway profile is shown in the lower right corner of the figure (extracted from the photogrammetry geometry by Archéovision Production)

occurred due to their low intensity. The scenario of single fires is thus more probable but not certain. Small-scale fires could also have been made outside the studied areas without leaving any traces. In total then, at least $170 \mathrm{~kg}$ of wood was burnt in the Megaceros Gallery according to the simulations.

Table 1 Characteristics of the thermo-alterations at each area. Likely order of magnitude of the wood masses which led to the thermo-alterations of each altered area in the Megaceros Gallery according to the simulations (in a single fire scenario). Minimum wood mass that had to be involved to generate the thermo-alterations in a scenario with several fires at each altered area (less wood could not induce mark)

\begin{tabular}{|c|c|c|c|c|c|}
\hline Area & $\begin{array}{l}\mathrm{Th} \text { e r m o- } \\
\text { alterations }\end{array}$ & $\begin{array}{l}\text { Height (m) [min; } \\
\max ]\end{array}$ & $\begin{array}{l}\text { Approximated surface area } \\
\left(\mathrm{m}^{2}\right)\end{array}$ & $\begin{array}{l}\text { Wood mass } \\
(\mathrm{kg}) \\
\text { Single fire }\end{array}$ & $\begin{array}{l}\text { Minimum mass } \\
(\mathrm{kg}) \\
\text { Several fires }\end{array}$ \\
\hline 1 & $\begin{array}{r}\text { Red, gray, } \\
\text { spalling }\end{array}$ & {$[0.9 ; 2.4]$} & 1.1 & [12-20] & $<10$ \\
\hline 2 & $\begin{array}{r}\text { Red, gray, } \\
\text { spalling }\end{array}$ & {$[1.8 ; 3]$} & $>0.65$ & [25-32] & 15 \\
\hline 3 & Red & {$[1 ; 1.7]$} & 0.75 & [16-21] & $<10$ \\
\hline 4 & Red, spalling & {$[0.9 ; 1.5]$} & 0.25 & $\leq 10$ & $<10$ \\
\hline 5 & $\begin{array}{r}\text { Red, gray, } \\
\text { spalling }\end{array}$ & {$[1.7 ; 3.3]$} & 1.15 & [31-38] & 20 \\
\hline 6 & Red, spalling & {$[1.3 ; 1.9]$} & 0.15 & [17-22] & $<10$ \\
\hline 7 & Red, spalling & {$[1.1 ; 2.1]$} & 0.45 & [15-20] & $<10$ \\
\hline 8 & $\begin{array}{r}\text { Red, gray, } \\
\text { spalling }\end{array}$ & {$[1.25 ; 2.8]$} & 1.3 & [22-27] & 15 \\
\hline 9 & Red & {$[1.4 ; 1.9]$} & 0.1 & [14-17] & $<10$ \\
\hline 10 & Red, spalling & {$[0.4 ; 2.2]$} & 1 & [12-15] & $<10$ \\
\hline
\end{tabular}



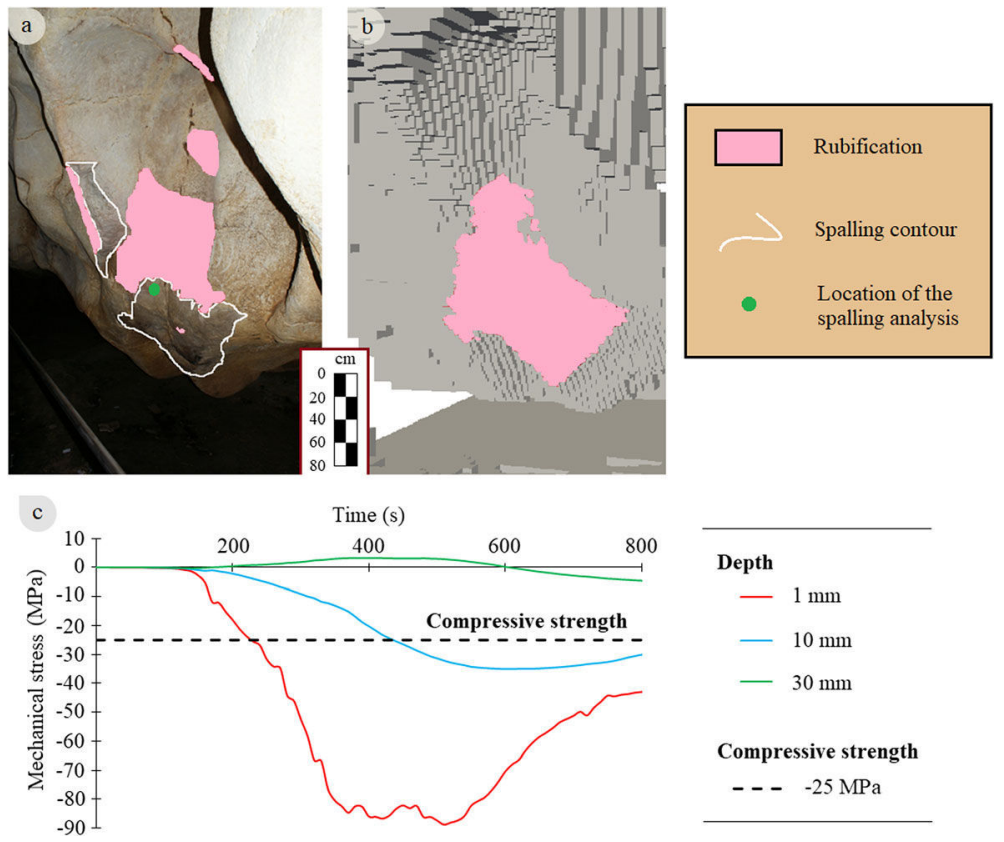

Fig. 3 As an example, this figure displays the comparison relating to the thermo-alterations of the 10th fire in the Megaceros Gallery. a Ground survey thermo-alterations of area 10 (MC-Chauvet Team). b Simulated rubification of area 10. Both the ground survey and simulation show similar color changes. $\mathrm{c}$ Evolution of the vertical compressive stress versus time at the green point (a) for several depths. Up to $10 \mathrm{~mm}$, the compressive strength is exceeded, which means that spalling is likely to occur. This agrees with the ground survey (a)

Based on simulation, our analysis of the fire hazards in the Megaceros Gallery shows that the fires were not a barrier to human circulation. Indeed, all the toxic gases were expelled into the Hillaire Chamber while the End Chamber was left empty of any toxic gases (Fig. 4). The Aurignacians could have stayed in the End Chamber under standard conditions during the fires. In addition, due to the large volume of the Hillaire Chamber, the toxicity remained low enough to allow short stays. Finally, due to the

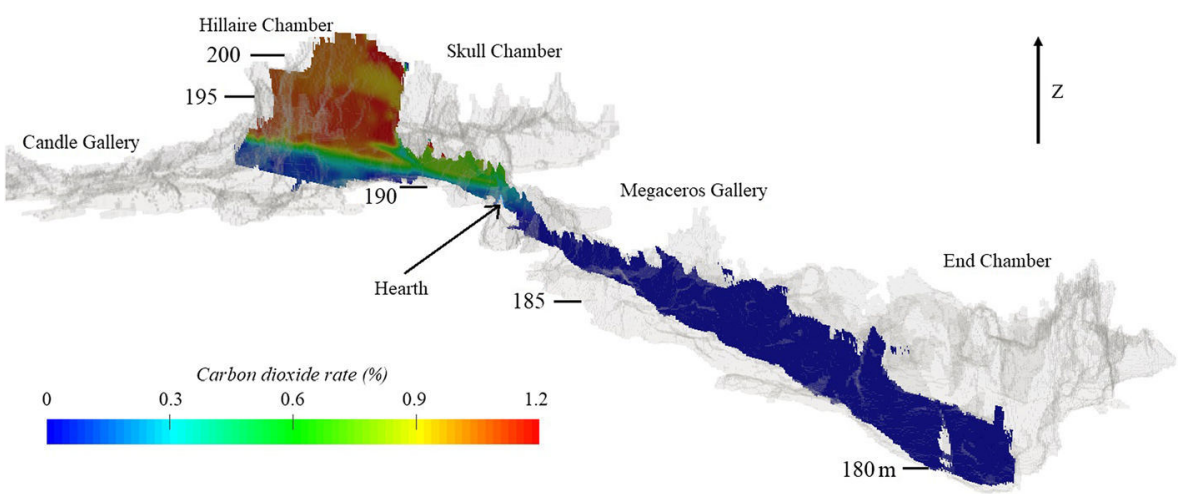

Fig. 4 Carbon dioxide rate $(\%)$ in the deep part of the Chauvet-Pont d'Arc Cave (Hillaire Chamber, Megaceros Gallery, and End Chamber) just after the combustion of $30 \mathrm{~kg}$ of wood at area 5 in the Megaceros Gallery. Like $\mathrm{CO}_{2}$, carbon monoxide remains harmless 
thermal stratification (Salmon et al. 2019) in the Megaceros Gallery, individuals in a squatting position (lower than 90-140 cm depending on the location) could have stayed near the hearths (from $1.5 \mathrm{~m}$ ) in the cold layer (at ambient temperature) during the fires.

The hearths were composed of up to a few dozen kilograms of wood (Table 1). Just a few individuals would thus have been necessary to gather and carry the branches deep into the cave. Personal tests made while gathering wood for the experimental fires (Ferrier et al. 2017) show that one single tree can supply about $10 \mathrm{~kg}$ of wood which can be collected by one person in about $12 \mathrm{~min}$. This does not encompass the shipping of wood from trees to the cave. These tests were achieved with the same possibilities as Aurignacians so only branches smaller than $4 \mathrm{~cm}$ in diameter and less than $2 \mathrm{~m}$ above the ground were broken by hand.

Some clues suggest that the hearths were shaped like tepees. The surface areas of all the thermally altered areas except 2,5 , and 8 are very small, indicating that the flames were very narrow and concentrated. For instance, in area 1 (Fig. 5), the color changes indicate that the wall was hotter in the gray zone $\left(>350^{\circ} \mathrm{C}\right.$ for $\left.10 \mathrm{~min}\right)$ than outside of it. Therefore, the flame would have impacted only the gray zone $(<50 \mathrm{~cm}$ in diameter) before spreading out along the wall with less impact. Given that the wood mass was between 15 and $20 \mathrm{~kg}$ (Table 1), the hearth was necessarily very compact. Otherwise, the affected surface would have been larger or nonexistent because the released power would have been less concentrated. Experiments (Dréan et al. 2017) showed that tepeeshaped hearths naturally produce high narrow flames (Fig. 6). On the contrary, flat carelessly entangled hearths lead to smallest and largest flames than tepee hearths with the same wood mass. Therefore, it seems very probable that the localized thermoalterations were generated by tepee-like hearths. The thermo-alterations in areas 2, 5,

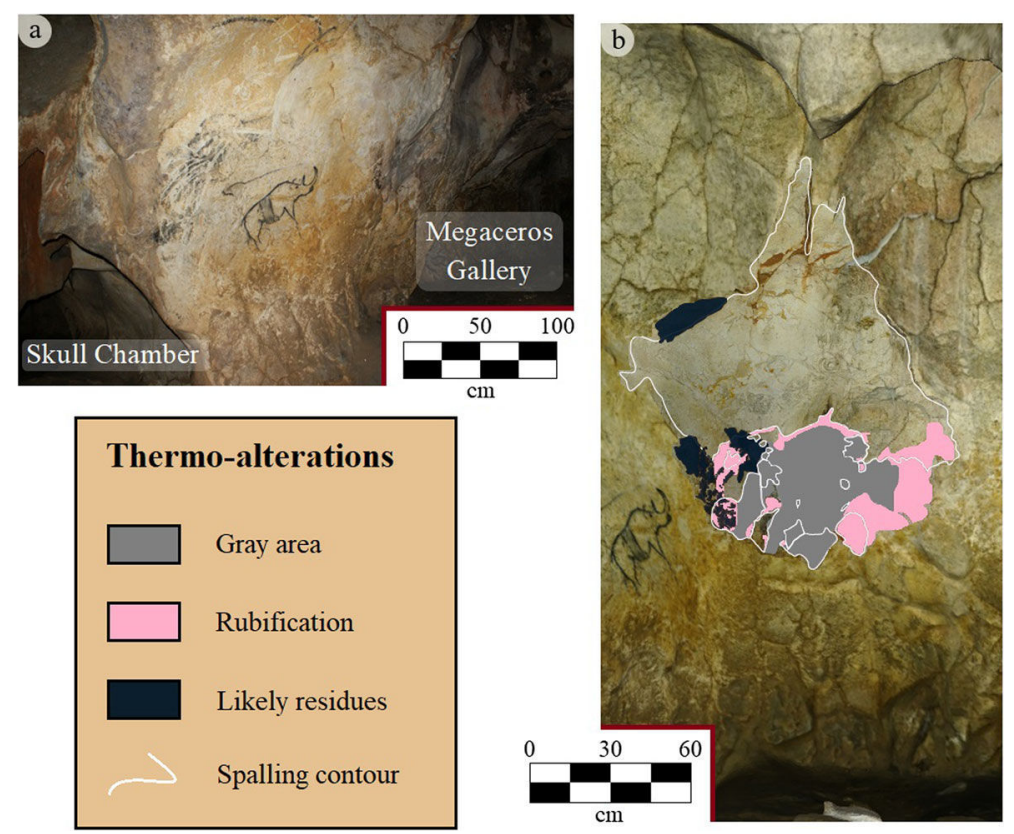

Fig. 5 a Thermo-alterations of area 1 at the entrance of the Megaceros Gallery (MC-Chauvet Team). b Thermo-alterations map of area 1 (front view) 


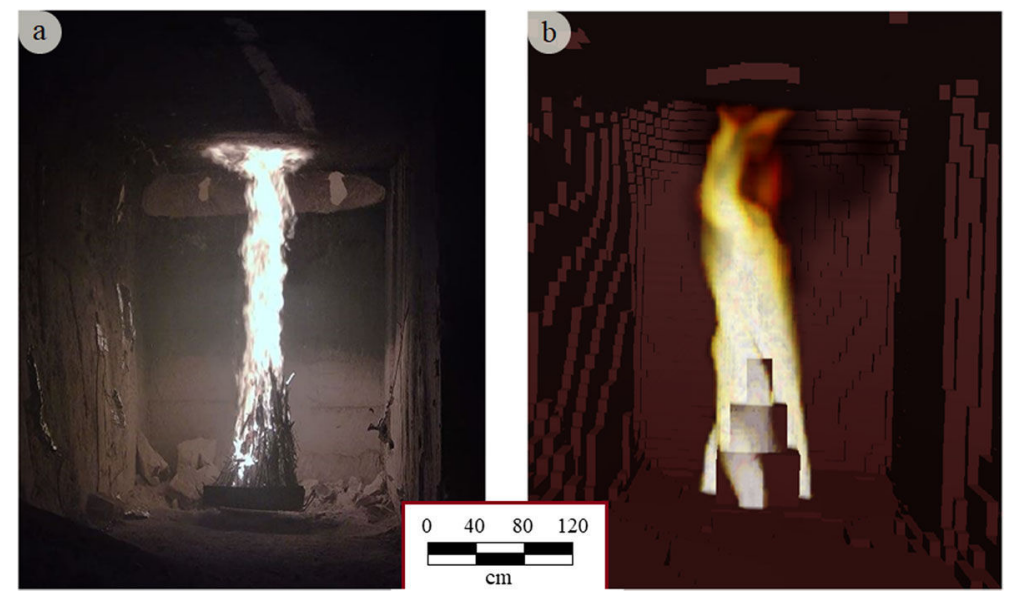

Fig. 6 a Combustion of a hearth in a tepee configuration composed of $16.8 \mathrm{~kg}$ of branches measuring approximately $80 \mathrm{~cm}$ long. The hearth diameter is approximately $80 \mathrm{~cm}$. The combustion process produced narrow flames $5 \mathrm{~min}$ after its ignition (MC-Chauvet Team). b Simulation of the fire 5 min after its ignition

and 8 extend across a broader surface since they correspond to the largest fires in the gallery (Table 1). However, our simulations suggest that the flames impacted a very restricted gray zone for these areas. The extension of these thermo-alterations would thus originate from the circulation of hot gases, not from the flame itself. Therefore, it is rather probable that the thermal-alterations of all the areas are the result of tepee-type hearths.

As stated in the introduction, the bottom of the walls of each area never displays thermo-alterations (at least $90 \mathrm{~cm}$ high). The numerical model reproduces this observation with hearths located a bit away from the walls (a few dozen centimeters at most). This matter was also noticed during some experiments in the abovementioned experimental quarry (Lacanette et al. 2017). The combustion of branches leaned against a wall necessarily generates color changes from the bottom or nothing if the fire is not enough powerful. Therefore, the most likely scenario that could have led to such thermal marks seems to be the combustion of tepee hearths, not in direct contact with the walls while being close to them.

The probable tepee arrangement of the hearths created tall and narrow flames that concentrated the energy and maximized the wall impact. Moreover, the location of the hearths away from the walls ensured a beneficial oxygenation all around the burning branches. On the contrary, a hearth leaned against a wall, which is an easier construction, would block out a part of oxygen supply since air would not be able to circulate between the branches and the wall. Since a greater oxygenation necessarily enhances the combustion process, both location and tepee arrangement optimized the release of energy which augmented the alteration of the vaulted ceilings. The similar characteristics of all the fires show that those who managed them shared the same skills and goals, whatever the time interval between each fire.

This kind of combustion does not foster charcoal production, even if some quantities are still generated. Instead, a poor combustion of a lighter random tangle of branches would have been more efficient at making charcoal. Given that these choices seem intentional, the main purpose of these fires could not have been to produce charcoal. 


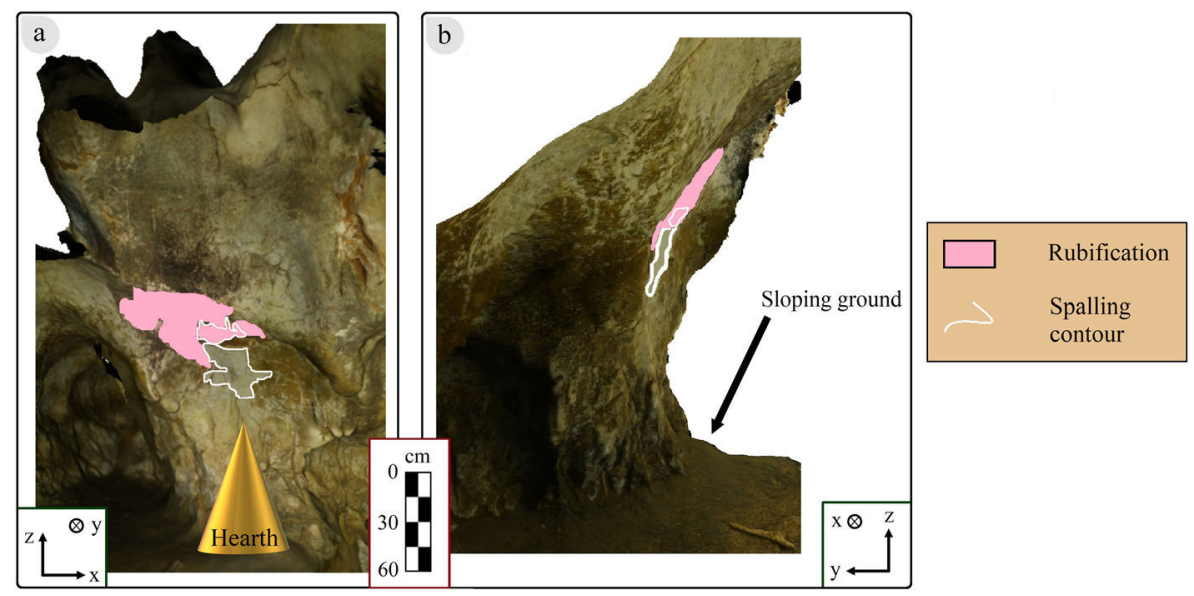

Fig. 7 Ground survey thermo-alterations of area 4 observed from two vantage points. a Front view. b Lateral view. The hearth (symbolized by the yellow cone) was located on the sloping ground but the flames had to impact the spalling zone without altering the bottom of the wall

One can wonder whether the locations of the hearths in the Megaceros Gallery (Fig. 2) have been rationally chosen. First, as already noted, the branches did not touch the walls. Second, the hearths were sometimes placed at inconvenient locations, such as in areas 4 (Fig. 7) and 9 (Fig. 8), whereas effortless positions were available just a few meters away. In area 4, the hearth was placed on sloping ground while, just $1 \mathrm{~m}$ away, a recess could have hosted the fire (Fig. 2). In area 9 (Figs. 2 and 8), a fire altered a rocky ledge at half height without altering the space underneath it. This means that the wood burnt exactly below the ledge boundary. Making the fire beneath the ledge or in the recess a few meters away (Fig. 2) would have made the living conditions less inconvenient around the fire.

Except for areas 5 and 8 (Fig. 2), all the thermo-alterations look alike, despite different ceiling heights. First, when a gray surface is observable, it is always small. Second, the red color extension often remains limited since, in most areas, it is caused by the flame impact rather than by the hot gases according to the simulations. This
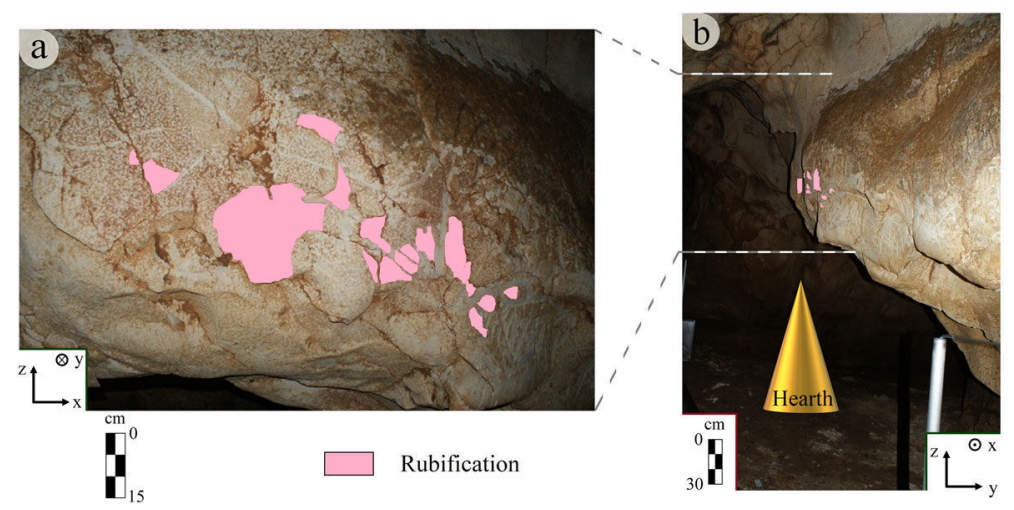

Fig. 8 Ground survey thermo-alterations of area 9 observed from two vantage points (MC-Chauvet Team). a Front view. b Lateral view. The hearth (symbolized by the yellow cone) had to be located just below the ledge boundary, which seems to be a very particular location 
similarity between the areas necessarily means that the hearths were tailored according to the ceiling height: the higher the impacted area, the larger the wood mass. For instance, in area 2 which is more than $2 \mathrm{~m}$ high, the simulation shows that about $30 \mathrm{~kg}$ of wood was burnt. In the other areas, the hearths always consisted of between 10 and $20 \mathrm{~kg}$ disposed under surfaces between $40 \mathrm{~cm}$ and $1.5 \mathrm{~m}$ high. As previously mentioned for area 9 , the combustion of about $15 \mathrm{~kg}$ of wood affected a rocky ledge, while the fire spared the ceiling. According to the simulation, a larger amount of wood $(\geq 20$ $\mathrm{kg}$ ) would have turned the ceiling red, whereas a smaller fire would not have transformed the rocky ledge. In short, the Aurignacians used a wood quantity that was adequate to turn the wall red without altering the ceiling. In addition to the particular location of the hearth (see prior paragraph), the fire characteristics might have been planned.

\section{Conclusion}

For conservation reasons, we developed a numerical tool that solves the equations governing the involved physical phenomena (combustion, heat transfer, fluid and solid mechanics). This consists of a coupling of two codes which was validated on fire experiments that we performed in a former quarry. The measurement of the energy released by the combustion of tepee hearths against time was also carried out since the developed approach needs it. With access to high-performance computing, we have run many fire scenarios in the Chauvet-Pont d'Arc Cave. In particular, we have tested different masses of wood and positions in the Megaceros Gallery. Our simulations and in situ observations enabled us to determine the main characteristics of the hearths (location, wood mass, configuration). At least ten separate fires burnt in the Megaceros Gallery (Fig. 2).

The configuration of the hearths was likely similar for all of them. The Aurignacians seem to have chosen tepee-shaped hearths. The latter were systematically positioned close to walls without touching them. The structure and position of the hearths optimized the release of energy. These characteristics suggest that charcoal production was not the only objective since they are not conducive to it. The large amount of burnt wood (at least $170 \mathrm{~kg}$ ) and the care taken to make the fires in the Megaceros Gallery below vaulted ceilings could rather suggest other functions. It is worth noting that these fires are located between two of the main painted areas (Panel of the Horses and End Chamber). The thermo-alterations of area 9 are associated with the Feline Panel (Fig. 8), which might have been drawn with fingers. Does this association result from intentionality? If so, a symbolic link between rock art and fire could thus exist. To better understand the functions attributed to these fires, the physical clues generated by this study must be confronted with archaeological knowledge. At the very least, the Aurignacians seem to have followed a rational plan that has never been reported in other caves.

Acknowledgments We wish to thank the Regional Council of Aquitaine and Nouvelle-Aquitaine for providing funding for the CarMoThap project and for their investment in a 432-processor cluster located in the I2M laboratory. This work was also performed using HPC resources from GENCI-CINES (Grant 2017A0032B10268). The researches in the Chauvet-Pont d'Arc Cave received specific financial help from the 
Ministry of Culture. We thank the LCPP (Laboratoire Centrale de la Préfecture de Police) for their help in the experiment instrumentation. We thank C. Bouchet, the owner of the quarry in Fauroux (Lugasson), and M. Vidal for having made available scots pine, as well as SDIS 33 staff for the participation in the experiments of the CarMoThaP program. We also express our gratitude to V. Feruglio for her comments and corrections.

\section{References}

Babrauskas, V. (2016). SFPE handbook of fire protection engineering, chapter Heat Release rates. Springer.

Beresnev, S., \& Chernyak, V. (1995). Thermophoresis of a spherical particle in rarefied gas: numerical analysis based on the model kinetic equations. Physics of Fluids, 7(7), 1743-1756.

Brodard, A., et al. (2014). Les rubéfactions des parois de la grotte Chauvet: une histoire de chauffe ?, Les arts de la Préhistoire : micro-analyses, mises en contextes et conservation. Paillet P. (dir).

Cast3m. Available: http://www-cast3m.cea.fr. [Accessed December 2019]

cfMesh. Available: http://cfmesh.com. [Accessed December 2019]

Chakrabarti, B., Yates, T., \& Lewry, A. (1996). Effect of fire damage on natural stonework in buildings. Construction and Building Materials, 10(17), 539-544.

Chauvet, J.-M., Brunel-Deschamp, E., \& Hillaire, C. (1995). La grotte Chauvet à Vallon-Pont-d'Arc. Paris: Éditions du Seuil, coll. Arts Rupestres.

Clottes, J. (2001). La grotte Chauvet. L'art des origines, Paris: Editions du Seuil, coll (p. 224). Arts Rupestres.

Coupling. Available: https://github.com/FabienSalmon/Couplage.git [Accessed December 2019].

Dréan, V. et al. (2017). Numerical modelling of thermal conditions during fires in cave-like geometry, 15th International Conference and Exhibition on Fire and Materials 2017, 1, 319-333.

Ferrier, C., et al. (2014). Les parois chauffées de la grotte Chauvet-Pont d'Arc (Ardèche): caractérisation et chronologie. PALEO, 25, 59-78.

Ferrier, C., et al. (2017). L'utilisation du feu dans l'endokarst au paléolithique: approche interdisciplinaire et expérimentale (programme CarMoThaP). Karstologia, 70, 23-32.

FireFOAM. Available: http://www.fmglobal.com/modeling. [Accessed December 2019]

Guibert, P., et al. (2015). When were the walls of the Chauvet-Pont d'Arc Cave heated ? A chronological approach by thermoluminescence. Quaternary Geochronology, 29, 36-47.

Lacanette, D., Mindeguia, J. C., Brodard, A., Ferrier, C., Guibert, P., Leblanc, J. C., Malaurent, P., \& Sirieix, C. (2017). Simulation of an experimental fire in an underground limestone quarry for the study of Paleolithic fires. International Journal of Thermal Sciences, 120, 1-18.

Leroi-Gourhan, A. (1965). Préhistoire de l'art occidental. Paris: Mazenod.

Liedgren, L., Hörnberg, G., Magnusson, T., \& Östlund, L. (2017). Heat impact and soil colors beneath hearths in northern Sweden. Journal of Archaeological Science, 79, 62-72.

Medina-Alcaide, M., Garate-Maidagan, D., Ruiz-Redondo, A., \& Sanchidrian-Torti, J. (2018). Beyond art: the internal archaeological context in Paleolithic decorated caves. Journal of Anthropological Archaeology, 49, $114-128$.

Mindeguia, J., Carré, H., Pimienta, P., \& Borderie, C. L. (2015). Experimental discussion on the mechanisms behind the fire spalling of concrete. Fire And Materials, 39(7), 619-635.

Purser, D. \& McAllister, J. (2016). SFPE handbook of fire protection engineering, chapter Assessment of hazards to occupants from smoke, toxic gases and heat, Springer.

Quiles, A., Valladas, H., Geneste, J. M., Clottes, J., Baffler, D., Berthier, B., Brock, F., Ramsey, C. B., Delqué-Količ, E., Dumoulin, J. P., Hajdas, I., Hippe, K., Hodgins, G. W. L., Hogg, A., Jull, A. J. T., Kaltnecker, E., de Martino, M., Oberlin, C., Petchey, F., Steier, P., Synal, H. A., van der Plicht, J., Wild, E. M., \& Zazzo, A. (2014). Second radiocarbon intercomparison program for the Chauvet-Pont d'Arc cave, Ardèche, France. Radiocarbon, 56(2), 833-850.

Quiles, A., Valladas, H., Bocherens, H., Delqué-Količ, E., Kaltnecker, E., van der Plicht, J., Delannoy, J. J., Feruglio, V., Fritz, C., Monney, J., Philippe, M., Tosello, G., Clottes, J., \& Geneste, J. M. (2016). A highprecision chronological model for the decorated Upper Paleolithic cave of Chauvet-Pont d'Arc, Ardèche, France. Proceedings of the National Academy of Sciences, 113(17), 4670-4675.

Ruan, H., Frost, R., Kloprogge, J., \& Duong, L. (2002). Infrared spectroscopy of goethite dehydroxylation: III. FT-IR microscopy of in situ of the thermal transformation of goethite to hematite. Spectrochimica Acta Part A, 58, 967-981. 
Salmon, F., et al. (2018). FireFOAM simulation of a localised fire in a gallery. Journal of Physics: Conference Series, 1107(042017).

Salmon, F., Lacanette, D., Mindeguia, J. C., Sirieix, C., Bellivier, A., Leblanc, J. C., \& Ferrier, C. (2019). Localized fire in a gallery: model development and validation. International Journal of Thermal Sciences, 139, 144-159.

Salmon, F., Lacanette, D., Mindeguia, J. C., Sirieix, C., Bellivier, A., Leblanc, J. C., \& Ferrier, C. (2020). Development of a fluid-structure coupling validated with a confined fire: application to painted caves. Fire Technology, 56(3), 1197-1227.

Speitel, L. C. (1996). Fractional effective dose model for post-crash aircraft survivability. Toxicology, 115(13), 167-177.

Théry-Parisot, I., Thiébault, S., Delannoy, J. J., Ferrier, C., Feruglio, V., Fritz, C., Gely, B., Guibert, P., Monney, J., Tosello, G., Clottes, J., \& Geneste, J. M. (2018). Illuminating the cave, drawing in black: wood charcoal analysis at Chauvet-Pont d'Arc. Antiquity, 92(1362), 320-333.

Valladas, H., et al. (2005). Bilan des datations carbone 14 effectuées sur des charbons de bois de la grotte Chauvet. Bulletin de la Société préhistorique française, 102-1, 109-113.

Walter, D., Buxbaum, G., \& Laqua, W. (2001). The mechanism of the thermal transformation from goethite to hematite. Journal of Thermal Analysis and Calorimetry, 63(3), 733-748.

Publisher's Note Springer Nature remains neutral with regard to jurisdictional claims in published maps and institutional affiliations. 